\title{
As leis do movimento do capital e a dinâmica dos capitais plurais na concorrência capitalista
}

\author{
André Cutrim Carvalho* \\ David Ferreira Carvalho**
}

\section{Resumo}

Este artigo tem como objetivo discutir, na perspectiva da lógica marxiana, ainda que não de forma exclusiva, o problema da mediação teórica e metodológica do capital em geral e as leis de movimento a que estariam sujeitas as formas dos capitais plurais ao nível da concorrência capitalista. Nesse particular, apesar dessa contribuição se manifestar no esforço de sistematização desse tema, o presente trabalho tem um caráter muito mais didático no sentido de contribuir para a divulgação dos trabalhos que estão sendo desenvolvidos sobre o tema da concorrência capitalista.

Palavras-chave: Capital em geral. Capitais plurais. Concorrência capitalista.

* Economista e Engenheiro de Computação. Mestre em Economia pelo Programa de Pós-Graduação em Ciência Econômica da UNESP. Doutor em Desenvolvimento Econômico pelo Instituto de Economia da Unicamp. Professor-pesquisador da Faculdade de Economia da Universidade Federal do Pará - FACECON/UFPA. E-mail: andrecc83@gmail.com

** Economista e Engenheiro Agrônomo. Mestre em Desenvolvimento Sustentável do Trópico Úmido pelo Núcleo de Altos Estudos da UFPA. Doutor e Pós-Doutor em Economia pelo Instituto de Economia da Unicamp. Professor-pesquisador da Faculdade de Economia e do Mestrado em Economia do Desenvolvimento Regional da Universidade Federal do Pará - FACECON/PPGE/UFPA. E-mail: david.fcarvalho@ yahoo.com.br

http://dx.doi.org/10.5335/rtee.v20i42.4481 


\section{Introdução}

Este ensaio tem como objetivo discutir, na perspectiva da lógica marxiana, embora não exclusivamente, o problema da mediação teórica e metodológica do capital em geral e as leis de movimento a que estariam sujeitas as formas subsumidas dos capitais plurais ao nível da concorrência. Não é correto transitar, desde as determinações do capital, em um nível mais geral e elevado de abstração em seu estado puro, até a dinâmica dos capitais individuais, em um plano particular e concreto, sem antes realizar as devidas mediações ao nível da concorrência, como o locus do enfrentamento dos capitais concretos. ${ }^{1}$

$\mathrm{Na}$ verdade, com a discussão que será apresentada adiante, pretende-se enfrentar a possibilidade de reconstrução teórica da dinâmica econômica capitalista, com base nas elaborações de Marx, pensando, porém, a concorrência como um nível de abstração privilegiado para incorporação de contribuições, as quais não são, necessariamente, marxistas. Não obstante, a concepção neoclássica da concorrência perfeita, bastante conhecida por meio dos manuais, não será tratada, devido ao pouco interesse para os objetivos desse ensaio.

De qualquer maneira, cabe ressaltar a premente necessidade de se construir uma teoria da concorrência como objeto teórico em si mesmo, com suas determinações próprias e específicas, e não mais uma teoria da concorrência genérica e subordinada, portanto sem estatuto teórico próprio, como a desenvolvida em $O$ Capital. A proposta é construída com base no conceito de concorrência de Marx, para desse derivar uma teoria da concorrência com status próprio. Em um primeiro momento, o esforço se dirige a identificar a pertinência do tema em seus contornos gerais e a sugerir, a partir de Marx, a trajetória apropriada na construção de uma proposta específica da teoria da concorrência, com características próprias e que seja abrangente o suficiente para incorporar outros elementos teórico-metodológicos capazes de integrar uma verdadeira análise da dinâmica econômica, como lembra Possas (1987, p. 25).

Tomar a concorrência capitalista, como objeto específico de teorização, se justifica, porque se torna necessária uma mediação teórica entre o capital em geral e as formas reais que os capitais plurais assumem no ciclo econômico reprodutivo do capital social; além disso, esse esforço analítico permite que, à concorrência, como uma instância privilegiada da acumulação capitalista, se possa incorporar - na medida do possível, e sempre procurando evitar o ecletismo vulgar-, as importantes contribuições teóricas desenvolvidas, sobretudo por Schumpeter Keynes, 
Kalecki, Steindl, acerca de determinadas questões analíticas ligadas às inovações tecnológicas, à demanda efetiva e à estrutura de mercado.

É claro que essa intenção não se esgota nesse texto. De qualquer modo, pretende-se contribuir para uma melhor compreensão da importante obra de Marx e, ao mesmo tempo, para estabelecer uma melhor articulação entre os teóricos supra citados, o que, de alguma forma, já vem sendo feito por alguns economistas. Apesar dessa contribuição se manifestar no esforço de sistematização desse tema, o presente texto tem um caráter didático, no sentido de contribuir para a divulgação dos trabalhos que estão sendo desenvolvidos sobre o tema da concorrência.

O presente ensaio foi organizado em três seções básicas, além dessa introdução e da conclusão. Na primeira seção, busca-se situar, sinteticamente, a trajetória histórica da metodologia desenvolvida por Marx para a elaboração de O Capital. $\mathrm{Na}$ segunda seção, o esforço se dirige para explicitar os significados dos conceitos do capital em geral e dos capitais plurais. Na terceira seção, discute-se a relação entre as leis gerais de movimento do capital em geral e as leis coercitivas próprias à dinâmica dos capitais plurais ao nível da concorrência, bem como a possibilidade de construção de uma teoria da concorrência capitalista em outras bases.

\section{Da estrutura original à estrutura modificada de O Capital}

No plano original, de 1857, a estrutura do que seria a obra magna de Marx estava dividida em seis livros, com uma longa introdução, em que seria também contemplada uma seção específica para a concorrência. Mas, ainda de acordo com o dito plano original, o livro sobre o capital ficaria dividido em quatro capítulos destinados a tratar: a) sobre o capital em geral; b) sobre a concorrência; c) sobre o crédito; e, d) sobre o capital acionário. No entanto, já em fins de 1858, Marx decidiu desistir da ideia de introdução por considerar contraproducente a antecipação de resultados que ainda caberia a ele demonstrar. Assim, os seis livros, originalmente planejados, se reduziram a um só: O Capital. O plano originário (1857) e o plano modificado (1866), segundo Rosdoslky (1985, p. 38 e 83) previam as seguintes estruturas para $O$ Capital: 


\section{Estrutura originária}

(6 livros)

I. O Livro do Capital em Geral

a) O Capital em Geral

1) Processo de Produção do Capital

2) Processo de Circulação do Capital

3) Lucro e Juros

b) A Concorrência

c) O Sistema de Crédito

d) O Capital Acionário

II. O Livro da Propriedade da Terra

III. O Livro do Trabalho Assalariado

IV. O Livro do Estado

V. O Livro do Comércio Exterior

\section{Estrutura modificada}

(3 tomos)

I. Processo de Produção do Capital

1) Mercadoria e Dinheiro

2) Transformação do Dinheiro em Capital

3-5) Mais -Valia Absoluta e Relativa

6) Salário

7) Processo de Acumulação

II. Processo de Circulação do Capital

III. Processo Global de Produção do Capital

VI. O Livro do Mercado Mundial e das Crises. 7)Rendas

Entre 1862-1863, Marx abdica de sua intenção inicial de tratar separadamente os problemas da concorrência, do sistema de crédito e do capital acionário no livro I de $O$ Capital. Para compensar, ele amplia progressivamente a primeira seção do livro I que trata do capital em geral. Entre 1865-1866, o novo plano estrutural de $O$ Capital adquiriu forma definitiva com quatro livros, a saber: livro I - $O$ processo de produção do capital; livro II - O processo de circulação do capital; livro III - O processo global de produção do capital; e livro IV - História da teoria.

Algumas das motivações de mudança da estrutura do plano original de Marx foram interpretadas por Grossmann e Behrens (ano) como resultantes da superação da metodologia da economia vulgar pela metodologia dialética. ${ }^{2}$ Mas, como foi observado por Rosdolsky (1985), esse não é o único, e tampouco o principal motivo da modificação da proposta original. Pelo contrário, a mudança do plano primitivo em direção à proposta modificada se deve a outros motivos em que se destacam a alta abrangência e a complexidade do objeto de análise de Marx, a sociedade capitalista. $^{3}$

No entanto, tão logo Marx teve pronta a sua análise teórico-histórica da lógica do capital industrial, a estrutura originária tornou-se supérflua, sem que isso significasse o abandono definitivo do conteúdo das suas partes constitutivas que acabaram sendo reincorporadas em $O$ Capital. De fato, dentre os principais manuscritos que serviram de base ao desenvolvimento dessa obra, os Grundrisse, 
diferentemente da posterior obra magna de Marx, O Capital, se restringiu essencialmente à análise do capital em geral, razão pela qual há uma abstração consciente de inúmeros problemas que só são tratados em profundidade em $O$ Capital (ROSDOLSKY, 1985, p. 36-50).

Os Grundrisse, assim esboçado por Marx entre 1857-1858, se limita, tal qual aos livros I e II de $O$ Capital, a enfocar, em toda a sua pureza, a essência dos processos de formação, de circulação e de reprodução do capital na sua forma fundamental, e, portanto, mais abstrata, que é a forma do capital em geral. Nesse nível de abstração, a análise de Marx toma, como hipótese geral, o pressuposto de que as mercadorias são vendidas por preços idênticos aos seus valores. De fato, no livro I, Marx não só desvenda o enigma do capital, ao descobrir o princípio da mais-valia e os métodos de extração, de exploração e de apropriação do trabalho não pago, como descobre as leis de movimento do capital em geral, pertinentes à acumulação, à concentração e à centralização do capital, sintetizadas na lei geral da acumulação capitalista.

No livro II, Marx tanto desvenda a forma sutil como o capital industrial se metamorfoseia no ciclo, quanto recompõe a forma social com que ele se reproduz e circula ampliadamente na forma de capital social. Assim, nos livros I e II, Marx desenvolve os seus estudos sobre a lógica do capital em geral ao nível do processo imediato de produção e do processo de circulação (MARX, 1980, L. 1, v. 2, cap. XXI-XXIII; L. 2, v. 3, cap. XX-XXI).

É no livro III de $O$ Capital, portanto, que Marx pretende estudar o processo de produção global, visto em sua totalidade, como uma unidade social interativa constituída pelos processos de produção e de circulação. Porém, o autor não pretende desenvolver considerações gerais sobre essa unidade social, "mas apenas descobrir e descrever as formas concretas [dos capitais plurais] oriundas do processo do movimento do capital [em geral] considerando esse processo como um todo" na forma de capital social global (MARX, 1980, p. 29).

Nesse ponto, Marx, já tendo descoberto, ao nível mais elevado de abstração, as leis de movimento do capital em geral, como forma social do capital indiferenciado, busca analisar o movimento real do capital em suas formas concretas de enfrentamento ao longo dos processos imediatos de produção e de circulação como esferas da concorrência, em que os capitais plurais assumem determinadas formas específicas que se metamorfoseiam permanentemente em cada fase do processo cíclico da produção global capitalista: capital dinheiro (D), capital produtivo (P) e capital mercadoria (M). Assim, Marx (1980, p. 29-30) avança paulatinamente sua análise sobre as manifestações dos fenômenos na superfície da sociedade burguesa, 
estuda a ação recíproca dos capitais concretos e a consciência habitual dos próprios agentes da produção acerca da concorrência.

É no volume 4 do livro III que Marx procura discutir os problemas da transformação da mais-valia em lucro e da taxa de mais-valia em taxa de lucro, da conversão lucro geral em lucro médio e a lei da tendência e contra tendência da queda da taxa de lucro. ${ }^{4}$ Percebe-se que, nesse volume, Marx procura transitar do nível de abstração do capital em geral para o dos capitais plurais para, assim, descobrir a forma como as leis que regem o primeiro se manifestam nos capitais concretos. Mas, antes de descrever as formas do capital mercantil no volume 5, do livro III, Marx discute a dinâmica capitalista, ao nível da concorrência, enfrentado aí os sérios problemas relativos à transformação dos valores em preços de produção e de mercado.

Após essas observações gerais, procurar-se-á, na seção seguinte, discutir a concepção do capital em geral, como forma social do capital não diferenciado, o seu status teórico, no nível mais geral de abstração, e a sua manifestação nas formas dos capitais plurais ao nível do movimento real. ${ }^{5}$

\section{$3 \mathrm{O}$ movimento do capital em geral e as formas subsumidas dos capitais plurais}

\section{$3.1 \mathrm{O}$ significado do capital em geral e dos capitais plurais}

Como vimos na seção 1, para tratar do capital em geral, os Grundrisse de Marx excluem, em princípio, os temas econômicos que serão, depois, abordados em O Capital. ${ }^{6}$ Mas, afinal, qual é o significado conceitual e o status teórico do capital em geral?

De início, pode-se dizer que o nível de abstração em que Marx formula o capital em geral exclui a concorrência e o sistema de crédito. Isso porque, é na concorrência que se manifesta concretamente a ação competitiva do capital sobre o capital, o que também pressupõe uma pluralidade dos capitais concretos. Enquanto no caso do crédito, o capital aparece, frente aos distintos capitais reais, na forma líquida de capital geral. De fato, nos dois casos, a análise de Marx restringe-se à lógica do movimento real dos capitais concretos, isso é, dos capitais reais e não do capital ideal, qual seja não diferenciado, tomado em sua totalidade social, abstrata (ROSDOLSKY, 1985, p. 70). Portanto, pode-se dizer que, para se investigar as leis gerais imanentes do capital, em seu estado puro, Marx procura abstrair a concorrência, 
e os fenômenos dela decorrentes, para partir do capital em si mesmo, ou seja, do capital em geral (ROSDOLSKY, 1985, p. 92).

Para alcançar a plena compreensão das leis gerais que regulam o movimento do capital em geral, Marx (1987,v. 2, p. 416) chega a admitir que a "introdução, de muitos capitais, não deve perturbar [sua] análise. A relação entre os muitos capitais, antes de tudo, se tornará clara tão logo se tenha considerado o que todo tem em comum: ser capital". Isso significa que, para compreender o significado de capital em toda sua plenitude, deve-se partir do capital em geral dada pela premissa básica da relação do capital - ou seja, da relação social de produção entre capital e trabalho e o papel que joga a mais-valia para o desenvolvimento das forças produtivas - e não dos capitais plurais.

Entretanto, o capital em geral existe, e só pode existir, como muitos capitais concretos. Com efeito, a autodeterminação do capital em geral se apresenta socialmente como uma ação reciproca dos capitais plurais em luta entre si e para si (MARX, 1987, p. 317; ROSDOLSKY, 1985, p. 70).

É claro que,

[...] quando o capital é débil, [Marx aqui está se referindo às formas pré-históricas do capital mercantil], esse se apoia nas muletas dos modos de produção pretéritos, subordinados ou que caducam com a aparição daquele. Mas, tão logo se sente robusto, como capital industrial, joga as muletas fora e se sustenta em suas próprias leis. Tão pronto comece a sentir-se a si mesmo como barreira ao desenvolvimento, recorre a formas que, ainda que pareçam dar os últimos toques ao domínio do capital moderandoa livre concorrência, ao próprio tempo anunciam a dissolução daquele e do modo de produção nele fundado (MARX, 1987, p. 544-45).

Porém, em sua época de [pleno] esplendor, o domínio do capital só pode concretizar-se na concorrência e através dela (ROSDOLSKY, 1985, p. 71).

Mas, prosseguindo, poderia o leitor se perguntar: quais características poderiam ser consideradas como comuns a todos os capitais concretos? É claro que se poderia responder, baseado em Marx, aquelas presentes em todas as formas do capital, enquanto uma forma social de riqueza historicamente determinada, porém distinta de outras formas de manifestação da riqueza ainda presentes no modo de produção capitalista, como veremos a seguir.

A economia burguesa, frequentemente, concebe o capital como trabalho morto, na forma trabalho acumulado e objetivado para servir como meio de produção para explorar o trabalho vivo. Nessa concepção, o capital é visto como algo material e se prescinde da sua forma social e histórica, é percebido como uma relação social, sem a qual não constitui capital. No entanto ainda queseja ainda que sirva como 
meio de produção para mercadorias reproduzíveis pelo trabalho assalariado, nem todo trabalho objetivado, - que serve como meio de produção, - é capital, como por exemplo, os casos em que esse não se sujeita à exploração do trabalho alheio.

Quando os economistas burgueses dizem que o capital é uma soma de valores aplicados na produção de valores, eles querem dizer que o capital é um valor de troca, como dinheiro, que se reproduz por si próprio. Porém, do ponto de vista formal, 0 valor de troca se reproduz também na circulação simples. Nessa visão, portanto, se explicita apenas a forma social que converte o valor de troca em ponto de partida do circuito do capital, mas se oculta à relação social contida nele (MARX, 1987, p. 169-171).

Afirma-se que o capital é o valor de troca que produz lucro, ou que pelo menos se faz uso dele com tal intenção, então a definição de capital se põe como uma relação, pois o lucro é uma relação social determinada consigo mesmo. Entretanto, o capital não é apenas uma relação social simples, mas também um processo social e historicamente determinado que, embora mude constantemente de forma em diversos momentos, ele nunca deixa de ser capital, como na forma social de riqueza de um modo de produção historicamente determinado - o capitalismo - que produz e reproduz coisas e gente pelo mecanismo do fetiche.

Mais do que isso, $O$ Capital, em geral, em sua forma abstrata mais pura ou mesmo em suas formas plurais especificas, próprias à divisão social do trabalho, é um processo em permanente contradição em si e para si, como uma relação social, cuja dinâmica quase sempre se manifesta em crise potencial ou efetiva, marcada por uma sistêmica instabilidade. Como se vê, a categoria capital é um conceito teórico-histórico complexo que tem vários significados.

Para alcançar o conceito de capital, portanto, é necessário [tomando a mercadoria] partir do valor e não do trabalho, e concretamente do valor de troca já desenvolvido no movimento da circulação. É tão impossível passar diretamente do trabalho ao capital, como passar diretamente das diversas raças humanas ao banqueiro ou da natureza à máquina a vapor. (MARX, 1987, p. 170-71).

O capital em geral é, portanto, uma forma social histórica que transforma todo conteúdo material da produção da riqueza social numa abstração de riqueza expressada nodinheiro, como representação social de poder no capitalismo. Por isso, a mercadoria, como forma existencial concreta do capital, só pode se realizar como valor de uso, se antes se realizar como valor de troca, isso é, se antes ela for trocada por dinheiro. Mas o dinheiro, equivalente geral, socialmente aceito no mercado, é uma forma de valor de troca específica que, sob determinadas condições históricas, assume a forma potencial de capital e, portanto, se torna a forma líquida de 
expressão geral da riqueza social, capaz de, na função de dinheiro em si mesmo, realizar como moeda as funções sociais de medida de valor, meio de circulação, meio de pagamento, reserva de valor e moeda universal.

Mas, não se pode confundir o dinheiro, como a primeira forma social de manifestação histórica do capital, com o próprio capital e nem se deve também considerá-lo como a única forma própria e líquida do capital (MARX, 1980, p. 77-79; MARX, 1987, p. 198-199). Na determinação do conceito de capital, como uma relação social de produção, Marx observa que estão presentes muitas dificuldades que não existem no caso específico do dinheiro. De fato, $O$ Capital é essencialmente o capitalista [personificado], porém, ao mesmo tempo, é, por sua vez, elemento diferente da [persona] do capitalista, no papel de figura do produtor em geral.

Assim, encontra-se sob a categoria capital muitos elementos subsumidos que, segundo o seu conceito geral, não parecem estar dentro dele: por exemplo, o capital se empresta, se acumula, é valor e é dinheiro. Em todas essas relações, entretanto, o capital parece ser apenas uma coisa que coincide com a matéria em que consiste a relação (MARX, 1987, p. 412-413).

Mas, precisamente, o que distingue o capital do mero valor ou do dinheiro é, antes de tudo, o fato de que o capital é um valor que contém em si mesmo um plus-valor que está baseado numa relação social específica do capitalismo, portanto, historicamente determinada, que é antes de tudo uma relação social fundamentada na exploração do trabalho assalariado. No modo social de produção especificamente capitalista, a produção e a reprodução de capitalistas e de trabalhadores é, por conseguinte, um produto social fundamental do processo de valorização do capital.

Nesse processo de valorização do capital, diz Marx (1987, p. 412),

[...] o trabalho objetivado é posto ao mesmo tempo como [trabalho] não objetivado do trabalhador, como objetividade de uma subjetividade contraposta ao trabalhador, como propriedade de uma vontade alheia a ele, [assim] o capital é ao mesmo tempo necessariamente o capitalista e a idéia de alguns socialistas [utópicos] de que precisamos do capital, porém não do capitalista, é inteiramente falsa. No conceito de capital está posto que as condições objetivas do trabalho, e estas são o próprio produto do capital, assumem frente a este uma personalidade ou, o que dá no mesmo, que sejam postas como propriedade de uma personalidade alheia.

Nesse conceito de capital, como uma histórica relação social que sujeita os trabalhadores despossuídos de meios de produção aos capitalistas, está contido também o próprio capitalista como persona. Os economistas, que só conseguem ver as coisas produzidas, esquecem desse fetiche completamente. Marx, porém, não 
está preocupado com uma forma particular do capital e, nem tampouco, com esse ou aquele capital naquilo que os capitais plurais se diferenciam, em si e entre si, em sua forma e função. Depois de descobrir a gênese e o movimento real do capital, Marx desvenda o enigma das relações sociais de produção capitalista que permite o processo contraditório de expansão do capital.

$\mathrm{Na}$ acumulação do capital, o que se revela comum a todos os capitais, independente de sua forma ou função, é fato de que a propriedade de toda produção de mercadoria ser baseada na exploração do trabalho alheio, ou seja, o fato de que capitalistas se apropriam, direta ou indiretamente, do plus-valor gerado no processo de produção capitalista, como processo de trabalho e de valorização do capital.

Por isso, Marx não inicia a sua pesquisa científica pelo processo de circulação simples dos capitais concretos, mas, ao contrário. A sua análise do capital em geral começa investigando o processo de produção. E nisso, o autor descobre como o dinheiro, ultrapassando sua determinação simples como dinheiro, se transforma em capital, como o consumo produtivo do trabalho assalariado engendra plus-valor e, por fim, como a produção desse plus-valor leva à reprodução ampliada do capital e da própria relação social capitalista.

Toda essa descoberta científica - da gênese e do funcionamento do capital - foi levada adiante sem a necessidade de Marx ter levado em conta, em um primeiro momento da sua investigação, a existência dos diversos capitais concretos e nem as diferenças entre eles. Isso porque Marx percebeu que, qualquer que fosse a distribuição entre os capitais individuais da mais-valia gerada ao nível do processo de produção, "nunca os capitais concretos [poderiam] dividir entre eles mais do que plus-valor total ou o surplus-produto total" (MARX, 1987, p. 673).

De fato, ao nível da concorrência, o surplus-produto total jamais pode explicar a origem da mais-valia senão, pelo contrário, pode até obscurecê-la. Isso porque, no lucro dos capitais concretos, o plus-valor aparece como igualmente criado por todos os capitais individuais, como frações do capital social, e o próprio capital social global, fonte de riqueza, independente do trabalho.

Por isso que Marx, para desvendar o enigma do capital e compreender a premissa fundamental da relação capitalista - a relação entre o capital, o trabalho e o papel do plus-valor como propulsor da produção capitalista - não partiu dos capitais concretos plurais ao nível da concorrência, mas antes do capital indiferenciado de toda a sociedade, quer dizer do capital em geral. Só assim, como observa muito bem Rosdolsky (1985, p. 74) foi possível Marx desenvolver em toda a sua plenitude o conceito de capital. 


\section{$3.2 \mathrm{O}$ capital em geral e as formas dos capitais plurais}

O capital em movimento não se limita ao processo imediato de produção. Para que o capital possa constantemente renovar-se, acrescido de um plus-valor, deve assumir várias formas a começar pelo capital - dinheiro. Nessa dinâmica cíclica reprodutiva do capital, a fase do processo de produção imediato deve completar-se com a fase da circulação. O movimento do capital, assim, se converte num incessante processo de circulação em que as formas dos capitais plurais - capital mercadoria, capital produtivo (capital fixo, circulante e capital variável) e capital líquido (dinheiro) - assumem determinações idiossincráticas e transitórias de capitais individuais, enquanto formas concretas de existência do capital em geral.

No entanto, essas formas concretas dos capitais plurais são apenas diferenciações singulares dentro do nível de abstração do capital em geral - as quais caracterizam todo tipo de capital - o qual, por sua vez, não considera a interação recíproca dos capitais plurais. Todavia, as diversas fases de circulação do capital funcionam como uma barreira à fase produtiva, já que a circulação toma tempo - durante o qual esse capital circulante não pode criar plus-valor.

Assim, a produção capitalista, como um sistema produtor de mais-valia, não depende apenas do tempo de produção, tempo em que o capital cria valores, mas, também, do tempo de circulação, durante o qual ditos valores, na forma de mercadorias, são realizados no mercado (MARX, 1987, p. 521). Portanto, a repetição do processo de produção, por inteiro, depende também do tempo de circulação, ou melhor, da velocidade da circulação, de forma que, quanto mais rápido se produzir as mercadorias, tanto mais breve será o tempo de circulação e tantas vezes mais o mesmo capital pode repetir o processo de produção.

Mas, esse processo de renovação periódico e cíclico da acumulação ampliada do capital - que implica a passagem da forma circular da reprodução simples à forma de espiral da reprodução ampliada - a qual supõe a primeira - sempre pressupõe a forma D-D' ou P-P', nunca a forma M-M', em que o capital reaparece como capital-dinheiro ou como capital produtivo pronto para reiniciar um novo ciclo. ${ }^{7}$ Por isso, a rotação do capital é concebida como tendo seu ciclo definido como um processo periódico que se renova e não como um acontecimento isolado. ${ }^{8}$

Cabe observar que, da mesma forma que a mercadoria é a unidade imediata do valor de uso e do valor de troca, o processo de produção capitalista, que é um processo de produção de mercadorias, é também a unidade imediata do processo de trabalho e do processo de valorização do capital. A transformação de dinheiro adiantado, destinado a valorizar-se e a transformar-se em capital, em fatores do 
processo de produção, constitui-se num ato do processo de circulação de mercadorias produtivas, isso é, na compra de meios de produção e de força de trabalho produtiva, realizando-se fora do processo imediato de produção.

Mas, se em vez do processo imediato de produção, tomarmos o conjunto e a continuidade progressiva da produção global capitalista, essa transformação de dinheiro nos fatores do processo de produção se constitui em um momento imanente do processo de produção global do capital social (MARX, 1975, p. 29-33). Portanto, pode-se dizer que, no modo de produção capitalista, um capital de um valor social determinado produz, num determinado lapso de tempo, um plus-valor determinado. Com efeito, a mais-valia assume a forma transformada e derivada do lucro, e a taxa de mais-valia, a forma de taxa de lucro (MARX, 1980, L. 3, cap. III-VI).

Ademais, o capital social global, em seu movimento incessante, se desdobra, gerando uma riqueza social que não se confunde com ele e, por isso, não se constitui em riqueza social fixa, mas em uma parte elástica da riqueza social, a qual flutua constantemente com a divisão da mais-valia social em renda e capital adicional. "Por esta via, o próprio capital social global põe o seu outro, cria a sua exterioridade, particularizando-se como capital nacional e generalizando-se globalmente na forma de capitais trans-nacionais" (GIANNOTTI, 1984, p. 280-281).

Cabe observar que, diferentemente dos capitais individuais, o capital social global é o capital de toda a classe capitalista. Assim, somente o lucro social global da classe capitalista pode, teoricamente, coincidir com a mais-valia social global, ada qual a classe dominante se apropria, ainda que seja produzida pela classe dominada, os trabalhadores. Mas, dada uma taxa geral de lucro e sua correspondente transformação de valores em preços de produção, a apropriação do lucro global entre os diversos capitais concretos pressupõe a concorrência e, portanto, não cabe ser examinada ao nível do capital em geral. De fato, nos Grundrisse, Marx (1987, p. 352-354) observa:

O capital em geral, diferentemente dos capitais particulares, se apresenta, a bem da verdade: 1)apenas como uma abstração, não uma abstração arbitrária, mas uma abstração que capta a diferença específica do capital em oposição a todas as demais formas de riqueza ou modos em que a produção(social) se desenvolve. Trata-se de determinações que são comuns a cada capital enquanto tal, ou que fazem de cada soma determinada de valores um capital. E as diferenças dentro desta abstração são igualmente particularidades abstratas que caracterizam toda espécie de capital, ao ser sua afirmação ou negação (por exemplo, capital fixo ou circulante); 2) porém o capital em geral, distinto dos capitais reais em particular, é ele próprio uma existência real. 
A economia vulgar reconhece este fato, ainda que não o compreenda, pois isto constitui um momento muito importante em sua teoria das compensações, etc. Por exemplo, o capital, nesta forma universa l(geral), ainda que pertencente a diversos capitalistas, em sua forma elementar como capital, constitui o capital que se acumula nos bancos ou se distribui através deles e, como diz Ricardo, se distribui tão admiravelmente na proporção das necessidades da produção. Constitui igualmente, via empréstimos, etc., um nível entre os distintos países. Por conseguinte, é uma lei do capital em geral, por exemplo, que para valorizar-se ter de se pôr duplamente e ter de valorizar-se sob essa forma dupla. Por exemplo, o capital de uma nação particular, que em contraposição a outra representa par excellence o capital, deverá ser emprestado a uma terceira nação para que seja possível a sua valorização.

Esta dupla posição, este relacionar-se consigo mesmo como um estranho, torna-se, neste caso, diabolicamente real. Embora o universal seja, de um lado, apenas uma diferença específica ideal, é também, por sua vez, uma forma real particular ao lado da forma do particular e do singular. (Nous reviendrons plus tard sur ce point qui,quoique d'un caractère plus logique qu'économiste, prouvera néanmoins d'une grande importance dans le progrès de notre recherche).O mesmo ocorre na álgebra. Por exemplo, a, b, c, são números em geral, mas, além disso, são números inteiros frente a a/b, b/c, c/a, b/a, etc., que os pressupõe na qualidade de elementos gerais.

Marx (1987, p. 735-736) é bem mais claro sobre seu conceito de capital em geral, numa outra passagem dos Grundrisse, quando afirma:

O capital em geral, não é uma mera abstração. Se, por exemplo, considero o capital global de uma nação, por contraposição ao trabalho assalariado total (ou, igualmente, à propriedade da terra),ou se tomo o capital como uma base econômica geral de uma classe por oposição a outra classe, eu o estou considerando em geral. Assim como, por exemplo, considero fisiologicamente o homem por oposição ao animal. A diferença real entre o lucro e o juro existe como a diferença entre uma classe de capitalistas banqueiros e capitalistas industriais. Porém para que essas duas classes possam contrapor-se, sua existência real dual pressupõe uma divisão da mais-valia gerada pelo capital [...] O importante é que o juro e o lucro expressam, ambos, relações do capital. Como forma particular, o capital que rende juros não se contrapõe ao trabalho, mas sim ao capital que produz lucros.

Essas duas longas afirmações de Marx são muito importantes, por exemplo, para se compreender a dinâmica do capital geral em seu movimento cíclico global, como capital social global, correspondente ao processo interativo e iterativo de contínua produção, reprodução e circulação do capital industrial em geral e de suas formas específicas de manifestação, configuradas no capital-dinheiro, capital-produtivo e capital-mercadoria. Em seu ciclo global, os ciclos dos capitais individuais se entrelaçam, se pressupõem e se condicionam uns com os outros nessa dinâmica. É precisamente esse entrosamento que constitui o movimento conjunto do capital social (MARX, 1980, p. 102-103).

De fato, em seu movimento global cíclico entrelaçado, o capital industrial social global assume várias formas específicas e transfiguradas - capital-dinheiro, 
capital-produtivo e capital-mercadoria - correspondentes às funções do capital bancário, do capital industrial e do capital comercial. ${ }^{9} \mathrm{Na}$ forma geral do ciclo global do capital, D-M-P-M'-D', de certo modo já estão contidas as formas individuais e específicas que o capital social assume em seu incessante movimento. Cada ciclo particular traz implícito o outro e, ainda, a repetição de um ciclo, sob uma forma, implica a realização do ciclo sob as demais formas.

Quando se considera cada um desses ciclos, como forma particular do movimento [social global] em que se encontram diferentes capitais industriais individuais, essa diversidade só existe do ponto de vista formal.

$\mathrm{Na}$ realidade, cada capital industrial individual encontra-se em todos os três [ciclos] ao mesmo tempo. Os três ciclos, as formas de reprodução das três figuras do capital, efetuam-se continuamente um ao lado do outro. [...] A reprodução do capital em cada uma de suas formas e em cada um de seus estádios é contínua, do mesmo modo que a mudança dessas formas e a passagem sucessiva pelos três estádios. Aqui, portanto, o ciclo total é unidade efetiva de suas três formas (BALIBAR, 1980, p. 103).

Por isso, o verdadeiro ciclo do capital industrial em sua continuidade é, além de unidade do processo de circulação e do processo de produção, unidade de todos os três ciclos. Mas o capital aparece como um valor que se preserva e se acresce um mais-valor num movimento que percorre uma série de modificações conexas, interativamente determinadas, uma série de metamorfoses que se constituem e se desenvolvem como fases de um processo global. Em cada uma dessas fases, ou estádios, o valor capital se encontra sob diferentes formas específicas, cada uma correspondendo a uma função diversa. No estágio final desse movimento, que na verdade não se interrompe, o valor-capital adiantado, que se apresenta preservado e acrescido de uma dada magnitude, volta a mesma forma com que iniciou o processo global cíclico (BALIBAR, 1980, p. 103).

Esse processo cíclico global do capital se desenrola em duas fases pertencentes às esferas da circulação e da produção. Na esfera da circulação, entretanto, o valor-capital adiantado assume duas formas, a de capital-dinheiro (D) e a de capital mercadoria (M); e na esfera da produção, a forma de capital produtivo $(\mathrm{P}) .{ }^{10} \mathrm{O}$ capital social global, que no desenrolar de todo o seu ciclo, ora assume ora abandona essas formas específicas do capital em geral, executando por meio de cada uma delas uma função correspondente, é o capital industrial que, no sentido de Marx, compreende todo ramo de produção explorado segundo a lógica do modo de produção especificamente capitalista.

Nesse sentido, capital-dinheiro, capital-produtivo e capital-mercadoria não representam, a rigor, espécies autônomas do capital, cujas funções estejam ligadas 
ao conteúdo de ramos de atividade, igualmente autônomos e separados uns dos outros como resultado da divisão do trabalho, mas são formas específicas de funcionamento do capital industrial global que as assume sucessivamente (MARX, 1980, p. 52-53). O capital industrial é o único modo de existência do capital em que esse tem por função não só apropriar-se da mais-valia ou do produto excedente, mas também criá-la, reproduzi-la e ampliá-la. ${ }^{11}$

No livro 2 de $O$ Capital, quando Marx discute o ciclo reprodutivo do capital - mercadoria, a partir da formula geral, M'-D'-M....P....M', ele observa que o ciclo M'....M' supõe, em seu próprio decurso, outro capital industrial sob a forma M (=Ft $+\mathrm{Mp}$ ) na qual Ft se põe como capital variável (força de trabalho assalariada) e Mp compreendendo as diversas formas do capital constante (meios de produção) - seja de capital fixo (máquinas e equipamentos), seja de capital circulante (matérias-primas e matérias secundárias). ${ }^{12}$ Para Marx (1980, p. 98-99):

Justamente por isso, convém considera-lo: forma geral do ciclo, isto é, forma social sob a qual pode ser observado cada capital industrial isolado (exceto em seu primeiro emprego), forma de movimento, portanto, comum a todos os capitais industriais individuais, e, além disso, forma de movimento da soma dos capitais individuais, por conseguinte do capital global da classe capitalista. Nesse movimento do capital global, o de cada capital industrial individual, aparece como movimento parcial que se entrosa com os outros movimentos, sendo por eles condicionado. Quando observamos, por exemplo, a totalidade do produto anual de mercadorias de um país e analisamos o movimento com que uma parte desse produto repõe o capital produtivo em todos os negócios individuais, e outra parte entra no consumo individual das diferentes classes, M'....M' se patenteia forma de movimento do capital social e da mais-valia por este produzida, ou seja, do produto excedente. O capital social = soma dos capitais individuais (inclusive os capitais das sociedades por ações e os do Estado, nos casos em que o governo funciona como capitalista industrial, empregando trabalho assalariado produtivo em minas, ferrovias, etc.), e o movimento global do capital social = soma algébrica dos movimentos dos capitais individuais. As duas igualdades não possibilitam que o movimento do capital individual isolado manifeste fenômenos diferentes dos apresentados pelo mesmo movimento, quando considerado parte do movimento global do capital social, portanto em sua conexão com os movimentos das outras partes desse capital, nem que o movimento global resolva problemas cuja solução tem de ser pressuposta quando se estuda o ciclo de um capital individual, em vez de resultar desse estudo.

O capital em geral só tem existência real na forma de capitais plurais, e, por isso, seu movimento de autodeterminação aparece no âmbito da anarquia da produção como sua interação. Nessa perspectiva, os diversos capitais individuais se põem como frações do capital social, cujo movimento é tanto seu movimento individual quanto, simultaneamente, elo integrante do movimento do capital global, o qual, apesar de ser só a soma dos capitais individuais, revela um caráter distinto de qualquer capital individual. ${ }^{13}$

Teoria e Evidência Econômica - Ano 20, n. 42, p. 157-194, jan./jun. 2014 
Dessa forma, o capital global da sociedade, capital industrial, deve ser concebido como uma totalidade social com existência real distinta dos diferentes capitais plurais concretos. Mas, a natureza real do capital social global se manifesta com maior clareza na forma de capital acionário, "modalidade sob a qual o capital está elaborado até sua última forma e na qual está posto não somente em si, segundo sua substância, como também segundo a sua forma enquanto força e produto social”, como lembra Marx (1987, p. 428).

Mas, o capital é a própria contradição em processo, já que o capital, como produtor de valores de troca encontra sua barreira na produção alheia, do mesmo modo que, como produtor de valores de uso, encontra sua barreira no consumo alheio. Dessa contradição entre produção e realização, nasce a concorrência (MARX,1987, p. 305-309). Isso porque, o capital, como produção de valor, produz valor de uso, na medida em que seja também um valor de troca, isso é, um produto para ser vendido no mercado, sou seja, uma mercadoria. Mas, além disso, a produção de um valor de uso qualquer é levada a cabo se ele contiver mais valor do que a soma dos valores das mercadorias produtivas necessárias para a sua produção. Por isso, os diferentes capitais plurais produzem mercadorias não para atender diretamente o consumo social, mas, sim, para se apropriarem de uma parte da mais-social produzida na forma de dinheiro.

Essa contradição entre produção e realização de mercadorias na forma de dinheiro, com equivalente geral determina que os capitais individuais entrem numa disputa acirrada entre si para conquistar parcelas do mercado. Mas, nessa disputa pelo mercado para transformar suas respectivas quantidades de mais-valia produzidas na forma de dinheiro uns ganham e outros perdem, segundo a lei geral de apropriação - na medida em que os capitais plurais podem receber um equivalente maior ou menor de tempo de trabalho abstrato socialmente necessário do que o contido em suas mercadorias na forma de lucro - do lucro no mercado. Essa capacidade de conquistar e ampliar mercados, por parte dos capitais individuais, depende da produtividade técnica-econômica de cada um deles, o que força a permanente busca pelo desenvolvimento de inovações de métodos e técnicas. Dessa forma cada capital acaba realizando, sem ter consciência desse fato, as leis internas do capital que, em geral, ditam a cada capital individual a lógica da produção pelo lucro.

Com isso, conclui-se o que se tinha a dizer nesse nível de abstração sobre o conceito do capital em geral, essediferentemente dos capitais plurais, em nível da realidade concreta. No entanto, observando que todos os determinantes do capital em geral que aparecem implícitos em si adquirem uma realidade autônoma, manifesta quando esse capital, em geral, se apresenta realmente em seu movimento 
como capitais plurais. Cabe, agora, discutir as leis que regem a dinâmica dos capitais plurais.

\section{As leis do movimento do capital em geral e a dinâmica dos capitais plurais}

\subsection{As leis do movimento do capital em geral}

Não se pretende, nessa seção, rediscutir a teoria do valor no capitalismo, como teoria da mais-valia, mas apenas situá-la, de início, como uma lei geral de apropriação imanente ao capital em geral e, portanto, à qual estão sujeitas todas as formas sociais fenomênicas dos capitais plurais concretos, como capitais que se apropriam da mais-valia com vista à valorização progressiva.

No modo de produção especificamente capitalista, como forma mais desenvolvida da economia mercantil, tem-se a generalização da mercantilização, justamente porque as relações sociais de produção e a troca de mercadorias, as quais eram realizadas por produtores independentes, dão lugar, sob condições historicamente determinadas, às relações sociais de produção e a trocas capitalistas na medida em que a separação dos produtores diretos dos seus meios de produção transforma esses meios e a força de trabalho em mercadorias produtivas, sisso é, em capital-mercadoria e força de trabalho-mercadoria ${ }^{14}$.

É importante avisar que, embora Marx tenha tomado a sociedade mercantil simples como categoria dialética para fins de sua análise num estado puro das trocas, não se deve supor que ele tenha partido da sociedade mercantil simples como uma sociedade concreta cujo desenvolvimento histórico levou a emergência da sociedade capitalista. Ao contrário, seu ponto de partida é a sociedade capitalista, enquanto organização histórica de produção [mercantil] mais desenvolvida e mais variada que existe.

Para Marx (1980, p. 682-683):

Enquanto se observam as leis de troca em cada ato de troca isoladamente considerado, pode o modo de apropriação experimentar uma transformação total, sem que se fira de qualquer modo o direito de propriedade inerente à produção de mercadorias. Esse direito vigora não só na época inicial em que o produto pertence a quem o produz e em que esse produtor, trocando equivalente por equivalente, só pode enriquecer-se com o próprio trabalho; esse direito vigora também no período capitalista em que a riqueza social em proporção cada vez torna-se propriedade daqueles que estão em condições de apropriar-se continuamente de trabalho não-pago. 
Esse resultado torna-se inevitável, quando a força de trabalho é vendida livremente como mercadoria pelo próprio trabalhador. Mas só a partir de então, generaliza-se a produção de mercadorias que se torna que se torna forma típica de produção; só a partir de então, todo produto que se faz é destinado à venda, desde a sua origem, e toda a riqueza produzida passa pela circulação. A produção de mercadorias só se impõe a toda a sociedade e [só] desenvolve suas potencialidades ocultas, quando o trabalho assalariado se torna sua base.

Nessas formas, capital e força de trabalho irão se confrontar no processo de troca na esfera da circulação, segundo a lei do valor-trabalho. Nesse momento, o capital, como trabalho morto, só se contrapõe à força de trabalho, na sua forma social de trabalho vivo, como valor cuja única finalidade é sua autovalorização, o que é alcançado sugando o trabalho vivo, tal qual um vampiro. Portanto, como observa Marx (1980, p. 683),

[...] [dizer] que a interferência do trabalho assalariado vicia a produção de mercadorias é dizer que a produção de mercadorias para manter-se pura, não deve desenvolver-se. Essa se desenvolve de acordo com suas leis imanentes, convertendo-se em produção capitalista, e, na mesma extensão, as leis de propriedade inerentes à produção de mercadorias se transformam em leis de apropriação capitalista.

O momento histórico da conversão do dinheiro em capital é, ao mesmo tempo, o momento lógico da conversão das determinações mercantis em determinações capitalistas. Porém, isso não significou a supressão das relações mercantis, mas a generalização (inclusive da própria força de trabalho) e a adequação ao modo de produção especificamente capitalista. É também esse o momento lógico da transformação da lei do valor da produção mercantil simples em lei de valorização da produção capitalista.

Com base nessa ideia disso, portanto, a lei do valor é lei de apropriação e regulação do processo de criação de valores no capitalismo, isto é, uma lei imanente do próprio processo de valorização do capital. É nesse sentido, portanto, que o processo de produção, como unidade do processo de trabalho (valores de uso) e do processo de produção (valores de troca) se põe como um processo de produção de mercadorias carregadas de mais-valor, ou seja, como um processo de produção capitalista, como unidade do processo de trabalho e do processo de valorização do capital (plusvalor), ou melhor, como uma forma social capitalista de produção de mercadorias. ${ }^{15}$ De fato, no Capítulo Inédito D’o Capital, Marx (1975, p. 46) reafirma:

O processo de produção é a unidade imediata do processo de trabalho e do processo de valorização, assim como o seu resultado, o resultado imediato, a mercadoria, é a unidade imediata do valor de uso e do valor de troca. Mas o processo de trabalho não é mais do que um meio do processo de valorização, processo que, por sua vez, enquanto tal é essencialmente produção de mais-valia, isto é, processo de objetivação do trabalho não pago. 
Nesse particular, cabe observar que Marx parte da mercadoria para desvendar os mecanismos de funcionamento da sociedade capitalista como forma avançada da sociedade mercantil. ${ }^{16}$ Nessa perspectiva, a lei do valor, como lei geral de todo modo de produção mercantil, se transforma numa lei de valorização do capital no modo de produção especificamente capitalista. Essa transfiguração da forma do valor, entretanto, não é simples resultado de um hábil jogo conceitual de Marx, mas uma consequência da transformação social das relações de produção e de troca simples entre produtores independentes, expressas por meio, do valor, em relações de produção e troca especificamente capitalistas e que acabam determinando - isso sem nenhuma violação da lei do valor, apenas com uma transfiguração histórica na forma do valor expressar tais relações (MARX, 1980, p. 679-680).

Na medida em que a produção mercantil se desenvolve e se generaliza, incorporando a própria força de trabalho como uma mercadoria, a lei do valor inerente à produção e à troca de mercadorias passa a se configurar, no modo capitalista de produção, como uma lei de apropriação e de valorização do capital. De fato, a descoberta de Marx de que a lei do valor da produção mercantil se impõe, sob o regime de produção capitalista, como lei da produção de mais-valia, significa que ela continua a expressar, sob a forma transfigurada, as relações capitalistas de produção, como formas desenvolvidas e genéricas das relações de produção mercantis (BELLUZZO, p. $79-89) .{ }^{17}$

Por isso, a lei da mais-valia, como a forma capitalista que assume a lei do valor, é a lei fundamental do movimento do capital em geral, imprimindo sua lógica de extração de mais-valia aos capitais plurais, próprio de uma sociedade industrial. Trata-se, portanto, de uma lei interna e geral do modo de produção especificamente capitalista, já que essa lei define a especificidade do movimento dos capitais no seu processo de produção e reprodução ampliada das mercadorias e das relações de produção capitalistas das classes que interagem para produzi-las, na medida em que não está sujeita à qualquer limitação exterior de necessidades sociais, mas apenas às necessidades internas de autovalorização progressiva do capital (MARX, 1980, p. 210-223).

Nesse sentido, à medida que a sociedade burguesa passa a reproduzir trabalhadores assalariados e capitalistas em escala ampliada, ficam dadas as condições históricas para a gênese do processo de acumulação de capital, que emerge do próprio antagonismo dessa relação social de produção, e, por conseguinte, se estabelece a dinâmica do próprio movimento de reprodução ampliada continua dessa relação. De fato, enquanto o capital se apresenta apenas sob as suas formas simples - mercadoria ou dinheiro - o capitalista aparece também sob as formas típicas de 
possuidor de mercadoria ou de possuidor do dinheiro de uma economia mercantil simples do tipo M-D-M. Por tal motivo, como observa Marx (1975, p. 29), "estes últimos não são capitalistas em si e para si. Assim, como a mercadoria e o dinheiro só se transformam em capital mediante determinadas premissas, também os possuidores de mercadorias e de dinheiro só se convertem em capitalistas dadas certas premissas" - o que supõe uma economia capitalista do tipo D-M-D'.

$\mathrm{Na}$ fase manufatureira, a mais-valia absoluta se realiza com o prolongamento da jornada de trabalho além do ponto em que o trabalhador produz apenas um equivalente ao valor de sua própria força de trabalho e com a apropriação pelo capital desse trabalho excedente não pago. Essa forma de mais valia absoluta caracteriza a subsunção formal na medida em que a relação social de produção já capitalista, além de assumir a forma monetária, se mantém ainda por laços extra-econômicos que sujeitam o trabalho ao capital numa base tecnológica artesanal, semelhante a dos regimes de produção pré - capitalistas. ${ }^{18}$

$\mathrm{Na}$ fase da maquinofatura, em que as premissas históricas já correspondem ao modo de produção especificamente capitalista, as premissas teóricas - dadas a partir da constituição do capital industrial em geral - supõem, nas condições sociais de produção e reprodução ampliada do capital e do trabalho assalariado como trabalho alheio não pago, a extração de mais-valia relativa na forma de uma subsunção real, a qual supõe a mudança da base tecnológica artesanal para a mecanizada e a constituição do departamento produtor de bens de produção, capaz de impulsionar o desenvolvimento das forças produtivas capitalistas ${ }^{19}$ Nesse aspecto, Marx (1975, p. 726-726) afirma:

Mas todos os métodos para elevar a força produtiva social do trabalho, surgidos sobre esse fundamento, são ao mesmo tempo métodos para elevar a produção da mais-valia ou do produto excedente que, por sua vez, é fator constitutivo de acumulação. São, portanto, ao mesmo tempo métodos para produzir capital com capital ou métodos para acelerar sua acumulação. A conversão contínua da mais-valia em capital se patenteia na magnitude crescente do capital que entra no processo de produção e se torna base da produção em escala ampliada, dos métodos que a acompanham para elevar a força produtiva do trabalho e acelerar a produção de mais-valia. Se certo grau de acumulação do capital se revela condição do modo de produção especificamente capitalista, este reagindo causa acumulação acelerada do capital.

Dessa forma, portanto, se pode dizer que o moderno processo de acumulação capitalista, baseado no avanço das forças produtivas tecno-científicas e socioeconômicas, nasce das entranhas do próprio modo de produção capitalista avançado, emergindo, como um produto histórico resultante do antagonismo das relações de produção, ao mesmo tempo em que se reproduz em escala continuamente ampliada. 
Assim, pode-se dizer que acumulação e reprodução ampliada são, na realidade, dois momentos imanentes do mesmo movimento do capital regulado pela lei do valor. A distinção desses dois momentos imanentes de um mesmo movimento permite que a forma desse movimento, em sua dinâmica teórica e histórica, se manifeste como tendência. De fato, para Balibar (1980, p. 264):

A análise da tendência do modo de produção capitalista produz o conceito da dependência do progresso das forças produtivas em relação à acumulação do capital, e portanto, do conceito da temporalidade própria do desenvolvimento das forças produtivas no modo de produção capitalista. Só esse movimento pode ser chamado [...] de dinâmica, isto é, movimento de desenvolvimento interior à estrutura e suficientemente determinado por ela (o movimento de acumulação), efetuando-se segundo um ritmo e velocidade próprios determinados pela estrutura, possuindo uma orientação necessária irreversível, e conservando (reproduzindo) indefinidamente em outra escala as propriedades da estrutura. O ritmo próprio da acumulação capitalista inscreve-se no ciclo das crises, ao passo que a sua velocidade própria exprime a "limitação" do desenvolvimento das forças produtivas, simultaneamente, [...] acelerado e retardado, isto é, a limitação recíproca das duas relações articuladas na estrutura ("forças produtivas, relações de produção capitalista").

Nesse sentido, fica bem evidenciada a dependência do avanço das forças produtivas em relação à acumulação de capital, como reprodução ampliada das relações sociais capitalistas, e, por conseguinte, do progresso técnico-científico como arma estratégica da concorrência entre os diversos capitais plurais. De fato, Marx, ao estabelecer a relação histórica entre o progresso das forças produtivas tecno-científica e sociais, acaba também efetuando a conexão teórica entre produtividade tecno-social do trabalho e a lei do valor na sua forma especificamente capitalista de valorização de capital. ${ }^{20}$ Assim, independente da vontade de quaisquer capitais individuais, essa lei de valorização do capital se converte em uma lei geral do modo produção capitalista.

A lei da acumulação, portanto, não é uma simples questão de opção do capitalista individual, mas uma necessidade própria a todo capital e que se realiza sempre através da concorrência horizontal entre eles, na sua luta incessante para excluir-se uns aos outros dos mercados que disputam. Por isso, cada capital individual busca, por meio das inovações técnicas de toda ordem, reduzir ao máximo os seus custos e elevar suas margens de lucro para obter uma renda diferencial, com a qual reforça a concorrência vertical sempre presente entre o capital e o trabalho, em proveito do capital. ${ }^{21}$

É nos capítulos históricos de $O$ Capital que Marx trata do processo histórico do surgimento das bases técnicas capitalistas, a partir da natureza e do próprio desenvolvimento das relações capitalistas de produção, e, com essas, discute a 
emergência e o desenvolvimento de um departamento produtor de bens de produção $\left(D_{1}\right)$ autônomo e endógeno, frente a um departamento produtor de bens de consumo de luxo e de bens de consumo assalariado $\left(\mathrm{D}_{2}\right) \cdot{ }^{22}$ Com isso, o capital remove os limites tecnológicos externos ao movimento de acumulação e reprodução ampliada, desembaraçando-se de quaisquer limites à produção em grande escala, a não ser aqueles fixados pela sua própria natureza. Nestes termos, para Marx (1975, L. 1, v. 2 , p. 726$)$.

A conversão contínua da mais-valia em capital se patenteia na magnitude crescente do capital que entra no processo de produção e se torna base da produção em escala ampliada, dos métodos que a acompanham para elevar a força produtiva do trabalho e acelerar a produção de mais-valia. Se certo grau de acumulação do capital se revela condição do modo de produção especificamente capitalista, este reagindo causa acumulação acelerada do capital. Com a acumulação do capital desenvolve - se o modo de produção especificamente capitalista e com o modo de produção especificamente capitalista a acumulação de capital.

É nesse sentido que, no capitalismo desenvolvido, a produção pela produção

[...] encontra agora seu veículo material, consubstanciado numa divisão social do trabalho em que o tempo de trabalho social se vincula de modo autônomo [e endógeno] à produção dos meios de produção. E esta dinâmica se exprime pela diminuição constante do trabalho vivo ou, sob outro prisma, pela elevação da composição orgânica do capital, o que equivale a dizer, pela exacerbação da busca da produção pela produção (BELLUZZO, idem, p. 97).

Por isso, Marx, só após ter realizado a conexão teórica e histórica entre a natureza da produção capitalista de valores de uso e a tendência à expansão ilimitada dos valores de troca neles implícitos, introduz os seus esquemas de reprodução, tendo também discutido a acumulação capitalista com todos os supostos dos efeitos das variações da composição orgânica e da taxa de mais-valia sobre a taxa de lucro geral, não só para explicar matematicamente o movimento do capital global, como também para preparar a discussão que segue no terceiro volume de $O$ Capital, sobre a concorrência e a crise. ${ }^{23}$

O capital é, assim, uma contradição viva em processo que contém, em si mesmo, a tendência à superprodução e à negação do trabalho imediato. A possibilidade formal das crises no capitalismo já está contida na própria mercadoria, em particular na sua contraposição ao dinheiro desde o circuito mercantil simples $\mathrm{M}-\mathrm{D}-\mathrm{M}$. Não obstante, essa possibilidade potencial da crise é apenas uma condição necessária, mas ainda não é suficiente para explicar as determinações das crises efetivas, sobretudo no circuito capitalista D - M - D'.

Por isso, as contradições imanentes da produção capitalista sempre se exteriorizam e se resolvem nas crises, para logo serem repostas, já que são constitutivas 
do modo de produção capitalista. As crises, portanto, exteriorizam e resolvem, momentaneamente, as contradições imanentes da produção capitalista, entretanto, não as extinguem. A natureza contraditória da crise encontra sua expressão teórica, mas acabada na formulação - síntese da lei da tendência decrescente da taxa de lucro (MARX, 1980, cap. XIII a XV).

Essa lei tendencial de queda da taxa de lucro apenas condensa as contradições imanentes da produção capitalista, na medida em que o próprio desenvolvimento das forças produtivas, ao incluir a elevação da composição orgânica do capital como resultado da relação interativa entre a composição técnica e a composição em valor - determina também o estreitamento da base da relação de produção capitalista - que se manifesta numa redução da massa dos trabalhadores assalariados em relação à acumulação ampliada do capital sobre a qual se apoia o processo de produção, de apropriação e de valorização do capital -. Por isso, "o capital é a própria contradição em processo, na medida em que a mesma lei que o compele a uma valorização progressiva acaba determinando um estreitamento da base sobre a qual se apoia esse processo de valorização" (BELLUZZO, 1980, p. 100).

$\mathrm{Na}$ verdade, a lei do valor ao transmudar-se em lei de apropriação capitalista e em lei da valorização do capital acaba também se convertendo em lei fundamental do próprio movimento do modo de produção capitalista que determina, de forma anárquica e não regulada, por meio da mediação em luta dos capitais plurais, o desenvolvimento das forças produtivas, a acumulação de capital e a reprodução material e social da civilização burguesa em condições de viabilidade econômica e de continuidade histórica. ${ }^{24}$

Sempre que uma parte da mais-valia obtida e realizada não se destina ao consumo pessoal do capitalista e é investida na aquisição de meios de produção e em força de trabalho adicionais, ou seja, investida como capital adicional (mais meios de produção e força de trabalho) num circuito contínuo, tem-se a acumulação de capital e a reprodução em escala ampliada. Entretanto, essa lei geral da acumulação do capital só se realiza implicando em outra, qual seja, a de que não são as necessidades sociais que determinam a escala de produção ampliada, mas sim, a própria escala de produção ampliada que determina a massa social de produtos que, para se converter em mercadorias, precisa se realizar reconvertendo-se em dinheiro. Com efeito, o desejo de cada capitalista individual é que cada mercadoria contenha o máximo possível de trabalho não pago e, isso, ele só consegue graças àà produção pela produção. ${ }^{25}$ Nesse particular, Marx (1975, p. 726) é bem claro: 
Todo capital individual é uma concentração mais ou menos dos meios de produção com o comando correspondente sobre um exército maior ou menor de trabalhadores. Cada acumulação se torna meio de nova acumulação. Ao ampliar-se a massa de riqueza que funciona como capital, a acumulação aumenta a concentração dessa riqueza nas mãos de capitalistas individuais e, em conseqüência, a base da produção em grande escala e dos métodos de produção especificamente capitalista. O crescimento do capital social, realiza-se através do crescimento de muitos capitais individuais. Não se alterando as demais condições, os capitais individuais e com eles a concentração dos meios de produção aumentam enquanto o capital social acresce. Ao mesmo tempo frações dos capitais originais destes se destacam e funcionam como novos capitais independentes. A divisão da fortuna nas famílias capitalistas, além de outros fatores, desempenha aí um papel importante.

A concentração do capital, portanto, é um processo primário que resulta da acumulação sucessiva de meios de produção nas mãos dos capitalistas individuais e implica, também, no crescimento do capital social global, como forma de expressão agregada dos muitos capitais individuais. A concentração do capital nas mãos de muitos capitais individuais exprime, também, a polarização da riqueza social concentrada nas mãos da classe capitalista como um produto da capitalização da mais-valia extraída da classe trabalhadora. Dos aspectos que caracterizam essa espécie de concentração de capital que depende diretamente da acumulação de capital e com essa se identifica: ${ }^{26}$

$1^{\circ}$ ) a crescente concentração dos meios de produção por parte de vários capitalistas individuais, não se alterando as demais condições, é limitada pelo grau de crescimento da riqueza social;

$2^{\underline{o}}$ ) a parte do capital social global localizada em cada ramo de produção distribui-se entre os vários capitais individuais que se confrontam como produtores de mercadorias, independentes uns dos outros e concorrendo entre si.

É bom observar que, além dessa concentração setorial do capital, a acumulação e a concentração que a acompanha estão dispersas em vários pontos do espaço geográfico. Ainda, o crescimento dos capitais individuais é estorvado pela formação dos novos capitais e pela fragmentação dos capitais existentes. Por isso, de um lado, a acumulação se manifesta como uma concentração crescente dos meios de produção, e do comando sobre a força de trabalho em termos setoriais e espaciais e, de outro, aparece como uma repulsão recíproca dos muitos capitais individuais. ${ }^{27}$

Contudo, essa dispersão do capital social global em muitos capitais individuais, ou a dispersão entre seus fragmentos, é contrariada pela força de atração existente entre eles. Nesse último caso, não se trata mais de simples concentração de meios de produção e de comando do trabalho pelos capitais individuais. De fato, o que se tem agora, nas próprias palavras de Marx (1980, p. 726), “é concentração dos capitais já formados, a supressão de sua autonomia individual, a expropriação 
do capitalista pelo capitalista, a transformação de muito capitais pequenos em poucos capitais grandes."

Esse processo denominado de centralização de capital se diferencia dos processos de concentração e de acumulação porque pressupõe apenas alteração na repartição dos capitais já existentes e que estão funcionando. De fato, a centralização de capital é um processo secundário de concentração, já que implica este último, que resulta da reunião de diversos capitais individuais num único. Nesse sentido, a centralização de capital significa o crescimento de determinados capitais isolados, por diversos métodos de aglutinação, sem que seja alterado o volume do capital social global, pois se trata apenas de uma redistribuição dos capitais já existentes. $O$ campo de atuação da centralização de capital, portanto, não está limitado nem pelo acréscimo absoluto da riqueza social, nem pelos limites absolutos da acumulação de capital.

A centralização de capital, portanto, exprime as relações de enfrentamento dos capitalistas individuais entre si, na medida em que o capital que se acumula nas mãos de um só capitalista resulta da ruína de uns pelos outros ou do acordo de uns com outros. A centralização de capital completa assim, de forma bem mais ágil, a tarefa da concentração e da acumulação de capital, capacitando o capitalista industrial a ampliar a escala de suas operações produtivas e/ou financeiras. A trajetória da centralização remete, portanto, à luta encarniçada dos capitais plurais ao nível da concorrência. De fato, para Marx (1980, p. 727):

A batalha da concorrência é conduzida por meio da redução dos preços das mercadorias. Não se alterando as demais circunstâncias, o barateamento das mercadorias depende da produtividade do trabalho, e esta da escala de produção. Os capitais grandes esmagam os pequenos. Demais, lembramos que, com o desenvolvimento do modo de produção capitalista, aumenta a dimensão mínima do capital individual exigido para levar avante um negócio em condições normais. Os capitais pequenos lançam-se assim nos ramos de produção de que a grande indústria se apossou apenas de maneira esporádica ou incompleta. A concorrência acirra-se então na razão direta do número e na inversa da magnitude dos capitais que se rivalizam. E acaba sempre com a derrota de muitos capitais pequenos, cujos capitais sempre soçobram ou se transferem para as mãos do vencedor.

Percebe-se, assim, que, em última instância, a missão histórica do sistema capitalista não é tanto gerar um número crescente de empregos aos trabalhadores em geral, mesmo porque a crescente elevação da produtividade social, decorrente do desenvolvimento das forças produtivas em geral, impulsionadas pelo progresso técnico-científico, gera crescente exclusão social, mas, sem produzir um crescente volume diversificado de mercadorias, em escala ampliada e a preços baratos. Para isso, a concorrência (sobretudo a monopolista), o crédito e as sociedades anônimas,

Teoria e Evidência Econômica - Ano 20, n. 42, p. 157-194, jan./jun. 2014 
bem como as inovações tecnológicas, se transformam em armas poderosas nas "batalhas da concorrência". ${ }^{28}$

Para Marx (1975, p. 728-729), a centralização do capital pelo método de fusão, por meio da organização das sociedades anônimas, é uma forma bem mais ágil do que o método mais lento da centralização pela via compulsória da anexação, como certos capitais individuais concentrados, ao tornarem-se centros de gravitação poderosos, quebram a coesão dos demais e absorvem os seus fragmentos. Mas as sociedades anônimas só prosperam onde se tem um amplo desenvolvimento dos mercados de capitais e dos mercados financeiros que aceleram a separação entre $o$ capital, a função e o capital propriedade. ${ }^{29}$

As leis do movimento do capital em geral, as leis da mais-valia, da acumulação, da concentração e da centralização do capital são sintetizadas por Marx numa lei geral, absoluta, a lei da acumulação capitalista que expressa a polarização social entre a riqueza e a pobreza de qualquer formação capitalista. Nas palavras de Marx (1980, p. 747):

Quanto maior a riqueza social, o capital em função, a dimensão e energia de seu crescimento e consequentemente a magnitude absoluta do proletariado e da força produtiva de seu trabalho, tanto maior o exército industrial de reserva. A força de trabalho disponível é ampliada pelas mesmas causas que aumentam a força expansiva do capital. A magnitude relativa do exército industrial de reserva cresce, portanto, com as potências da riqueza, mas, quanto maior o exército de reserva em relação ao exército ativo está na razão inversa do suplício de seu trabalho. E, ainda, quanto maiores essa camada de lázaros da classe trabalhadora e o exército industrial de reserva, tanto maior, usando-se a terminologia oficial, o pauperismo. Esse é lei geral, absoluta, da acumulação capitalista. Como todas as outras leis, é modificada por muitas circunstâncias que não nos cabe analisar aqui.

Percebe-se, pela última frase, que Marx, mais uma vez, reconhece a possibilidade histórica de modificação de quaisquer leis gerais que, para ele, não seriam eternas e, do mesmo modo, evidencia nas leis fundamentais do sistema social capitalista, o lado negativo do capitalismo, que os economistas oficiais sequer tentam refutar. Para Engels, (1868, p. 31), "Marx ressalta que essa formação social era necessária para desenvolver as forças produtivas sociais até um nível que torne possível um desenvolvimento igual e humanamente digno para todos os membros da sociedade". 


\subsection{A dinâmica dos capitais plurais ao nível da concorrência}

Na seção anterior, destacou-se que, apesar de Marx ter destacado o lugar estratégico da concorrência, ao analisar as "batalhas da concorrência", resultantes dos processos de acumulação, de concentração e de centralização, ainda assim, a esfera da concorrência não recebe um tratamento teórico autônomo e específico, pois se situa no nível do capital em geral. ${ }^{30}$ Entre os diferentes sentidos em que Marx emprega o conceito de concorrência, em $O$ Capital, há um que o situa no âmbito da lógica do movimento do capital em geral. ${ }^{31}$

De fato, após ter destacado o papel que o processo de autovalorização do capital assume no modo de produção, especificamente capitalista, e a forma como a lei do valor, como lei de valorização do capital, regula os fundamentos das leis de movimento do capital em geral (acumulação, concentração e centralização), Marx emprega no livro III de $O$ Capital uma noção de, ampla - como o lugar do enfrentamento dos capitais plurais - mas ainda no âmbito do capital em geral.

Não obstante, cabe lembrar que, apesar de Marx empregar o termo concorrência em vários sentidos com muita frequência, ele não chegou a elaborar uma teoria por estar fora do plano de sua principal obra, O Capital. De fato, nas palavras de Marx (1980, p. 953):

Ao estudar as relações de produção convertidas em coisas e em entidades autônomas em face dos representantes da produção, não analisamos como as interferências do comércio mundial, as conjunturas deste, os ciclos da indústria e do comércio, as alternativas de prosperidade e crise se patenteiam a esses agentes leis naturais de poder imenso e irresistível que os dominam, impondo - se cegamente como fatalidade. É que está fora do nosso plano estudar o movimento real da concorrência, sendo nosso propósito apenas analisar a organização interna do modo de produção capitalista de produção, de acordo com a média ideal, por assim dizer.

A concorrência é apresentada com destaque no livro III de $O$ Capital, no âmbito das leis gerais do movimento do capital. No entanto, ainda assim, a análise da concorrência entre os múltiplos capitais plurais se processa estritamente subordinada ao capital em geral. Ou seja, a concorrência não é estudada de forma autônoma na medida em que a análise exercita tão somente as funções de ajustes e desajustes do equilíbrio dos preços de produção e de mercado sem incorporar outras dimensões analíticas da concorrência. Não obstante, não há dúvida de que concorrência se constitui um campo relevante e susceptível de tratamento teórico adequado, no quadro das categorias e conceitos formulados por Marx, desde que

Teoria e Evidência Econômica - Ano 20, n. 42, p. 157-194, jan./jun. 2014 
a construção da análise seja submetida à necessária unidade (continuidade) entre o âmbito das leis de movimento do capital em geral e a dinâmica real dos capitais plurais em que se situa a concorrência. ${ }^{32}$

Nesse ponto, admite-se, apesar de algumas opiniões contrárias ${ }^{33}$, que se a concorrência "executa as leis imanentes do capital [em geral], é evidente que o faz de modos específicos, que compete à 'análise da concorrência' determinar, investigando sua sistematicidade e especificidade ao nível da estrutura de funcionamento e do curso histórico do capitalismo." No entanto, a construção de uma teoria da concorrência entre os capitais plurais deve emergir como objeto teórico próprio em suas especificidades para se chegar às determinações teóricas mais concretas da dinâmica capitalista. ${ }^{34} \mathrm{~A}$ importância dessa distinção está em poder delimitar o campo das "leis de movimento" ao nível do capital em geral vis-à-vis o campo das "leis coercitivas" dos capitais plurais em nível da dinâmica capitalista que pressupõe as estratégias competitivas de atuação efetiva das ações dos capitais individuais ao nível da concorrência capitalista, tema esse que extrapola o âmbito da construção de $O$ Capital. ${ }^{35}$

Nas palavras de Possas (1987, p. 58):

A concorrência capitalista, sob esse prisma, situa-se no mesmo plano das formas em que os múltiplos capitais se apresentam uns frente aos outros. Este plano não é unicamente o das aparências, mas também o de uma abstração, que corresponde à existência ao mesmo tempo real e conceitual dos vários capitais em ação. Neste sentido, a concorrência é em princípio um objeto de reflexão teórica tão legítima e conceituável quanto às formas de existência do capital e da mais-valia de que se ocupou Marx ao longo do Livro III d'O capital.

[...] o desenvolvimento da produção capitalista torna necessária a elevação contínua do capital empregado num empreendimento industrial, e a concorrência impõe a cada capitalista as leis imanentes do modo de produção capitalista de produção como leis coercitivas externas. Compele - o a expandir continuamente seu capital para conserva-lo, e só pode expando-lo por meio da acumulação progressiva.

A produção pela produção, pelo desenvolvimento das forças produtivas e a acumulação progressiva constituem uma lei imanente do modo de produção especificamente capitalista, no sentido de que são deduzidas e adequadas ao próprio conceito de capital, como valor que se autovaloriza por meio da apropriação do trabalho alheio não pago (MAZZUCCHELLI, 1985, p. 20). Ainda no Livro I de $O$ Capital, Marx (1980, p. 364) adianta que as "tendências gerais e necessárias do capital [em geral] devem ser distinguidas de suas formas [os capitais plurais] de manifestação." Mas, apesar dessa importante observação, Marx (1980, p. 364) não examina no livro I: 
[...] o modo como as leis imanentes da produção capitalista se manifestam no movimento dos capitais particulares, como se impõem coercitivamente na concorrência e surgem na consciência de cada capitalista sob a forma de motivos que o impelem à ação. Mas, desde já, está claro: a análise científica da concorrência só é possível depois de se compreender a natureza íntima do capital, do mesmo modo que só podemos entender o movimento aparente dos corpos celestes depois de conhecer seu verdadeiro movimento que não é perceptível aos sentidos.

Quando Marx discute, nos Grundrisse, a relação entre o capital em geral e os capitais plurais é para poder investigar em estado puro as leis imanentes ao capital em geral. Nesse ponto, Marx (1987, p. 259) é categórico: “Ainda não temos que nos ocupar aqui do intercâmbio entre uma pluralidade de capitais, tema que cabe na teoria da concorrência ou também da circulação dos capitais (crédito)." Para Marx, apesar das outras conotações que aparecem em sua obra, a concorrência é o locus da pluralidade dos capitais em que ocorre o enfrentamento recíproco, por vários meios, entre os capitais plurais nos diversos planos em que o mercado se faz presente ao nível da produção, da circulação (realização) e da distribuição da mais-valia. ${ }^{40}$

Na concorrência capitalista, a

[...] conquista pelo capital individual do lucro extraordinário envolve o aumento da produtividade e em geral o decréscimo dos custos de produção. A luta competitiva também tem lugar ao nível do valor de uso dos bens, as mudanças de qualidade dos produtos que influenciam a realização do valor das mercadorias [na circulação] e, dessa forma, as parcelas de mercado dos capitais individuais. Ademais, a concorrência se trava igualmente a respeito da distribuição da mais-valia entre os diferentes ramos de atividade (POSSAS, 1987, p. 59).

Nos Livros I e II, de $O$ Capital, Marx estuda respectivamente os processos de produção e circulação e chega mesmo a evidenciar o processo global de produção capitalista, como unidade dos processos de produção e circulação. Já no Livro III de $O$ Capital, Marx (1975, p. 29) "pretende descrever as formas concretas oriundas do processo de movimento do capital, considerando esse processo como um todo." Marx (1975, p. 29-30), porém, acrescenta:

Em seu movimento real, os capitais se enfrentam nessas formas concretas; em relação a elas, as figuras do capital no processo imediato de produção e no processo de circulação não passam de fases ou estados particulares. Assim, as configurações desenvolvidas neste livro abeiram - se gradualmente da forma em que aparecem na superfície da sociedade, na interação dos diversos capitais, na concorrência e ainda na consciência normal dos próprios agentes da produção. 
Contudo, em O Capital, sobretudo no tomo III, apesar de Marx incorporar algumas dimensões gerais da concorrência - conversão do lucro em lucro médio, desdobramento do lucro em lucro do empresário, juros do financista, etc - essa ainda se circunscreve ao âmbito da natureza geral do capital. De fato, no livro III de $O$ Capital, a compensação dos vários lucros para formar a taxa de lucro média recebe um tratamento apenas formal que visa demonstrar a transformação dos valores em preços de produção.

Na verdade, essa demonstração pressupõe a livre mobilidade dos capitais e é capaz de permitir a migração de capitais de esferas de produção em que a taxa de lucro é baixa para outras que se situam acima da taxa média de lucro. Portanto, nos capítulos IX e X do livro III de $O$ Capital, a noção de concorrência é formal, e não disruptiva, assim, cumpre papel heurístico: dado o conceito (taxa de lucro média) os capitais formais devem mover- se entre as esferas de produção de composição orgânica distintas. ${ }^{41}$

A livre mobilidade do capital pressupõe, formalmente - se a concorrência é supostamente livre - não só a possibilidade (ou a facilidade) de acesso dos capitais individuais às inovações tecnológicas em geral, mas também o acesso desses aos diferentes setores e ramos da atividade econômica. Portanto, a livre mobilidade do capital, englobando ambos os sentidos, compreende não só o fluxo de capitais entre os setores da economia capitalista, mas também a ausência de barreiras que impeçam o acesso de quaisquer capitais às condições que favoreçam a possibilidade de lucro de monopólio. ${ }^{42}$ No entanto, partindo de uma concepção restrita de livre mobilidade do capital, vinculada apenas ao movimento dos preços, um grupo de interpretes reduz a concorrência ao problema da formação dos preços de produção de equilíbrio (de setores ou de produtos) e à reprodução do sistema econômico pelos preços de reprodução no longo prazo.

$\mathrm{Na}$ verdade, se na análise da formação do valor, a concorrência ainda não nivela os lucros, na análise da formação dos preços de produção, a concorrência formal (conceitual) nivela os lucros à taxa média de lucro, mas, para isso, suprime-se qualquer diferenciação entre os capitais plurais, capaz de formar agrupamentos sociais diferenciados - com exceção das composições orgânicas. Para Coutinho (1997, p. 152-156), em particular, em um caso em que a concorrência processa-se interesferas (transformando valores em preços de produção) e noutra intraesfera (ao estabelecer o valor do mercado, porém ainda não os preços reais de mercado). Por isso, Marx (1987, p. 450), ao tratar da relação teórica existente entre o plano do capital em geral (leis imanentes) e da concorrência (leis coercitivas aos capitais plurais), esclarece: 
A concorrência, em suma, este motor essencial da economia burguesa, não estabelece as leis desta, senão que é o seu executor. Portanto, a illimited competition não é o pressuposto da verdade das leis econômicas, senão a conseqüência; a forma de manifestação em que se realiza sua necessidade. [...]. Por conseguinte, a concorrência não explica estas leis, senão que as ver; logo, não as produz. O inerente a natureza do capital é posto desde fora, como necessidade externa, pela concorrência, que não é outra coisa senão que muitos capitais se impõem, entre se e a si mesmos, as determinações imanentes do capital [geral].

Nesse particular, se a luta de classe no plano vertical, entre o capital e o trabalho, define-se ao nível do capital em geral, as leis gerais de movimento desse último, ao incitar o acirramento da luta de classe no plano horizontal, entre o capital contra o capital, por redução de custos, acaba engendrando o mecanismo do movimento real do confronto dos capitais plurais no âmbito da concorrência. No entanto, se é verdade que a concorrência executa as leis gerais de movimento, ao impor externamente aos capitais individuais suas determinações essenciais, então, é fundamental extrair dessa premissa algumas conclusões básicas:

A primeira delas, salvo melhor juízo, é de que a análise da concorrência se constitui, em si mesma, em um plano privilegiado da mediação teórica para o entendimento do movimento real dos capitais plurais. É somente por meio da concorrência e de suas leis de coercitivas de determinação aos capitais individuais - que, diga-se de passagem, são distintas das leis imanentes de determinação do capital em geral - que se torna possível a compreensão das formas reais da produção e da circulação capitalista. Aqui é preciso frisar que, apesar dessa mediação teórica ser fundamental para o entendimento da dinâmica econômica capitalista, Marx não chegou a desenvolver em todos os seus contornos uma completa teoria da concorrência, relegando-a ao eventual prosseguimento de sua obra. Nesse particular, como observa Mazzucchelli (1985, p. 52), é bom que se diga que o plano de análise da mediação teórica não se constitui num mero discurso sobre as formas fenomênicas fetichizadas ou das aparências.

A segunda conclusão sugere que, se as leis da concorrência se desenvolvem de forma invertida em relação àquelas que ocorrem ao nível do capital em geral, e se as leis coercitivas de determinação da concorrência são diferentes das leis imanentes de determinação do capital em geral, resulta inviável desvendar o plano da complexidade da dinâmica dos capitais concretos sem passar pela análise das formas da mediação, ou seja, do ambiente seletivo da concorrência. ${ }^{43}$ De fato, qualquer tentativa de dedução direta do movimento real dos capitais plurais, a partir das leis gerais do capital em geral, sem nenhuma medição teórica, se constitui em um dos graves erros da maioria dos marxistas ortodoxos. ${ }^{44}$ 
Por fim, como última conclusão, pode-se dizer que, se a concorrência intercapitalista realiza as leis internas do capital em geral. Assim, há que se reconhecer a prevalência da relação entre os capitais plurais sobre a relação entre o capital e o trabalho no movimento real do modo de produção capitalista. Ou seja, se as leis imanentes do capital em geral se realizam apenas por meio do enfrentamento entre os capitais plurais, a análise dessa realização - que configura o movimento real do capital - deve ser remetida, em primeira instância, ao âmbito da concorrência intercapitalista, e não ao confronto entre o capital e o trabalho. Assim como, ao contrário, na medida em que o resultado da concorrência intercapitalista confirma a determinação das leis do capital em geral para cada capital em particular, as relações entre o capital e o trabalho revelam-se então determinantes, em última instância.

Na passagem da manufatura à maquinofatura, a introdução da máquina pressupõe a necessidade de baratear o valor da força de trabalho com vista à introdução da mais-valia relativa ainda no plano do capital em geral. No entanto, se a mesma questão é vista do prisma da concorrência, portanto do movimento real dos capitais plurais, é a busca incessante dos capitais individuais para rebaixar o valor individual de suas mercadorias vis-à-vis, de seus competidores que determinam a introdução sistemática do progresso técnico.

Para Belluzzo (1980, p. 108), entretanto, é indiferente para o capitalista individual introduzir uma inovação tecnológica que rebaixe os custos dos salários (capital variável) ou reduza os custos dos insumos (capital circulante) ou ainda substitua com vantagens as despesas de uma máquina menos eficiente por outra mais eficiente (capital fixo). O que importa para o capital individual, no âmbito da concorrência, é que o avanço tecnológico lhe proporcione uma redução do valor privado da sua mercadoria abaixo do valor social médio que o mercado vem sancionando.

Isso significa que a concorrência comporta dois planos de análise: um genérico ao nível do capital em geral e outro específico ao nível da própria concorrência. Nesse último, talvez seja melhor pensar a concorrência não como um mecanismo estático de regulação ou ajuste de preços de equilíbrio, mas como um processo autodisruptivo, provocando incessante mutação em sua estrutura econômica, como pensado por Marx e Scumpeters por meio do conceito-síntese de destruição criadora. Não é à toa que Schumpeter reconhece a dívida que tem para com Marx, ao passo que este adianta a importância do progresso técnico como motor da dinâmica capitalista. 
De fato, sob esse ângulo,

[...] o essencial da tese schumpeteriana já havia sido percebido e explicado por Marx, não propriamente em razão da ênfase que dera à concentração/centralização do capital como resultado necessário do seu movimento, a que Schumpeter não deu a devida atenção, mas por ter destacado o papel central que a busca do lucro extraordinário ou [lucro] de monopólio (temporário) cumpre na introdução de inovações. Em síntese, essa postura teórica permite repensar a tradicional oposição entre concorrência e monopólio, passando este último a ser visto não como o contrário, mas como o próprio motivo fundamental da concorrência.

Para Possas (1987, p. 135-168), além da necessidade da introdução de outros elementos analíticos importantes para compor um quadro mais abrangente da concorrência, tais como: barreiras à entrada, preços limites e estrutura de mercado, capacidade produtiva, demanda efetiva e, com ela, o risco e a incerteza); a relação entre concorrência (ou padrões de concorrência) e o dinamismo do capitalismo monopolista remete à necessária inserção do capital financeiro e dos papéis que 0 Estado e a mega empresa transnacional passam a desempenhar numa economia globalizada, como destacado por Mello (1982) e Possas (1987, p. 169-178).

\section{Considerações finais}

Do exposto até aqui, podemos reter, à guisa de conclusão, os seguintes pontos: em primeiro lugar, percebe-se que há dois níveis de análise em que a concorrência pode ser tratada teoricamente: um do capital em geral e outro da pluralidade dos capitais. Em segundo lugar, a análise da concorrência constitui um plano de mediação teórica imprescindível para o entendimento do "movimento real do capital" em seu enfrentamento na forma concreta dos capitais plurais.

Em terceiro lugar, Marx não chegou a desenvolver de modo sistemático uma teoria da concorrência com estatuto próprio e específico. Em quarto lugar, as determinações reais da concorrência são distintas das determinações conceituais do capital em geral. Em quinto lugar, é impossível deduzir diretamente a dinâmica dos capitais plurais, a partir das leis baseadas no valor e na mais-valia, sem realizar uma mediação teórica. Em sexto lugar, salienta-se que ao nível da concorrência as relações entre capital e trabalho estão sujeitas às relações entre capital e capital. Em sétimo lugar, cabe reter que o movimento real do capital somente em última instância pode ser sublimado às determinações imanentes do capital em geral.

Por fim, deve-se compreender que somente por meio da concorrência é que os capitais plurais podem realizar dinamicamente sua lógica com força de lei social - não a livre concorrência da plena mobilidade do capital ou da tendência à equalização das taxas de lucro ou dos preços de equilíbrio - mas, sim, a concorrência como vetor das inovações tecnológicas, das mutações estruturais, das crises e das flutuações cíclicas, em suma, a concorrência como motor do capitalismo. 


\title{
The laws of motion of capital and the dynamics of competition in plural capital capitalist
}

\begin{abstract}
This article aims to discuss, from the perspective of Marxian logic, but not exclusively, the problem of theoretical and methodological mediation of capital in general and his laws of motion that would be subject to the plural forms of the level of capital capitalist competition. In this matter, in spite of that contribution to show in the effort of systematizing that theme, the present work has a much more didactic character in the sense of contributing for the popularization of the works that come being developed on the theme of capitalist competition.
\end{abstract}

Keywords: capital in general; capital plural; capitalist competition.

\section{Las leyes del movimiento de capital y la dinámica de la plural capital en la competencia capitalista}

\section{Resumen}

Este artículo tiene como objetivo discutir, desde la perspectiva de la lógica marxista, pero no exclusivamente, el problema de la mediación teórica y metodológica del capital en general y sus leyes del movimiento que estaría sujeto a las formas plurales de nivel de la competencia capitalista capital. En particular, a pesar de esta contribución se manifiesta en el esfuerzo de sistematizar este tema, este trabajo tiene un aspecto mucho más didáctica, en el sentido de contribuir a la difusión de la labor que se está desarrollado sobre el tema de la competencia capitalista

Palabras clave: Capital en general. Capital de plural. La competencia capitalista. 


\section{Notas}

1 Cabe reconhecer que na concorrência existe um vínculo teórico essencial entre as "leis gerais de movimento" e a "dinâmica econômica real", não significa dizer que a concorrência seja o único elemento mediador entre esses dois níveis. De fato, esse vínculo é uma condição necessária, sobretudo para construir uma teoria da concorrência como objeto teórico com estatuto próprio - não abordado suficientemente por Marx e com contribuições de outros autores a exemplo de Schumpeter - mais ainda não é uma condição suficiente para construir uma teoria da dinâmica capitalista que requer outros elementos - a exemplo de uma teoria das decisões a partir das contribuições de Keynes e outras mais - certamente não redutíveis à concorrência.

2 As primeiras ideias da obra magna de Marx - O Capital - estão por certo contidas nos Grundrisse (18571858), nos manuscritos de 1861-1863, composto de 21 cadernos num total de 1472 páginas, que continha a Contribuição à Crítica da Economia Política, publicado pela primeira vez em 1859, e a história do pensamento econômico sobre as Teorias da Mais -Valia, publicada pela primeira vez em 1905-1910 por Karl Kautsky.

3 Na verdade, o modo social de produção desta sociedade (capitalista), historicamente determinada, é dialeticamente estudado por Marx como um todo social orgânico em movimento, portanto, sujeito a determinadas transformações, a partir do que a totalidade e suas relações sociais se sobrepõem de forma multifacetada e determinante sobre as partes.

4 Ver as contundentes e esclarecedoras críticas desse ponto em Tavares (1978, cap. II).

5 As citações, em se tratando dos Grundrisse, seguirão a sequência numerada dos manuscritos contida nos "Elementos Fundamentales Para La Crítica da Economia Política (Grundrisse) 1857-1858)"e não da paginação dos seus três volumes que não seguem uma sequência.

6 Diz-se "em princípio" porque os Grundrisse, embora discorra sobre o capital em geral, contém também muitas digressões que só posteriormente vão aparecer em outras partes de O Capital.Ver carta de Marx a Engels (1974, p. 318).

7 O tempo em que determinado capital realiza uma circulação completa é igual à soma de seu tempo de circulação propriamente dito e de seu tempo de produção imediato. É o período em que o valor-capital se move, a partir do momento que ele é adiantado sob determinada forma até o momento que ele volta à mesma forma, seja na do capital-dinheiro, D-M(Ft+ Mp) ........M'(M+m)-D'(D+d), seja na forma do capital produtivo, P...M'-D'-M'(Ft + Mp)...P'. No entanto, na forma geral de M'-D'-M....P....M', ou mais especificamente na forma M'-M', o valor-capital não começa como valor adiantado e, sim, como valor-acrescido de mais-valia,como riqueza global sob a forma de mercadorias da qual o valor-adiantado é apenas uma parte. Não obstante, essa forma é de importância fundamental para se compreender o movimento dos capitais individuais em conexão com o movimento, o capital social global. Não é útil, entretanto, estudar essa forma M-M' do ponto de vista da rotação do capital já que esta começa sempre com o adiantamento do valor-capital - sob a forma de dinheiro ou mercadoria - e sempre exige a volta do valor-capital em rotação à forma em que foi adiantado acrescida do plus-valor. Ver a esse respeito os comentários de Marx (1980, 1.2 , cap. VII, p. 159-163).

8 A duração ou tempo de rotação do capital é dada pela soma do tempo de produção e do tempo de circulação do capital e mede o tempo de duração do período cíclico de renovação do capital para se repetir o processo de criação de mais-valia. É claro que esse tempo de rotação dos capitais varia em função dos diversos ramos de produção. Se chamarmos $\mathrm{R}$ o ano, a unidade natural de medida das rotações do capital, de $\mathrm{r}$, $\mathrm{o}$ tempo de rotação de determinado capital, e de $n$, o número de suas rotações, tem-se que n=R/r. Ver Marx (1980, l.2, cap. VII. p. 162-163).

9 Como lembra Balibar, quando discute o significado teórico e histórico da reprodução do capital em Marx, a teoria da reprodução do capital é a pesquisa deste entrosamento, deste entrelaçamento e, portanto, só por abstração se "pôde conceber o movimento do capital individual, uma abstração deformante, dado que o movimento do conjunto é mais complexo que uma simples soma” (BALIBAR, 1980, v. II, p. 220).

10 Há duas fases na esfera da circulação, a inicial, [D-M(Mp+Ft)], - quando o capital dinheiro (D) se transforma em capital produtivo (P) ao comprar as mercadorias produtivas,meios de produção (Mp) e força de trabalho (Ft)_e a final, M'-D', - quando as mercadorias acrescida de mais-valia (M'),resultantes do processo de produção, são vendidas e transformadas em dinheiro ( $\left.D^{\prime}=D+d\right)$ preservado (D) e acrescido de mais-valor monetário (d). Na esfera da produção, quando, além do D, parte deste valor d é reinvestido, há uma acumulação ampliada tal que o capital produtivo (P) é também ampliado para P'. Ver Marx (1980, 1.2 , v. 3, p. 52-53). 
11 Por isso, o capital industrial, quando se apodera da produção social de um País, determina não só caráter capitalista da produção, cuja existência implica na cooperação e antagonismo entre as classes capitalista e trabalhadora, como também passa a revolucionar as técnicas e a organização do processo de trabalho e com elas o padrão histórico da sociedade. Ver Marx (1980, 1.2, v. 3, p. 56-57).

12 Sobre o ciclo M'...M', ver Marx (1980, 1.2, v. 3, p. 99-101), e sobre o capital constante, ver Marx (1980, 1.2, v. 3, cap. VIII).

13 O mesmo é válido para o crédito, como observa Marx., como uma forma de capital coletivo potencial de uma classe na qual o capital procura seser por como distinto dos capitais individuais, e esses buscam-se por como capital a despeito de suas limitações quantitativas (MARX, 1987, v. 2, p. 551-552).

14 Ver Belluzzo (1980. p. 79). Por esse método, como diz Marx, as categorias que exprimem as relações dessa sociedade [burguesa] e que permitem compreender a sua estrutura permitem ao mesmo tempo perceber a estrutura e as relações de produção de todas as formas de sociedades desaparecidas, sobre cujas ruínas e elementos ela se edificou, de que certos vestígios, parcialmente ainda não apagados, continuam a subsistir nela, e de que certos signos, desenvolvendo-se nela, se enriquecem de toda significação.

15 Não se deve esquecer que Marx parte da mercadoria, como forma mais geral e ao mesmo tempo mais simples da produção mercantil, razão por que surgiu nos primórdios, tomada na sua forma social plenamente desenvolvida da produção capitalista. Ver Marx (1980, Livro 1, v. 1. p. 92).

16 É por isso que a sociedade mercantil simples é o primeiro passo de sua análise da sociedade capitalista. Este método tem a vantagem, não só de possibilitar o estudo da troca em seu estado puro, próprio de uma sociedade de produtores independentes em que as relações de produção se resolvem por inteiro na divisão social do trabalho, como de permitir que as categorias da sociedade capitalista apareçam como forma historicamente transformada das sociedades econômicas pretéritas. Como se vê, o percurso da análise não é apenas lógico-dialético, mas também histórico-genético.

17 Portanto, da mesma forma como a lei do valor, numa sociedade mercantil de produtores independentes, garante que a quantidade total do trabalho consumido se reparta entre os diversos setores de produção em proporções tais que permita a reprodução simples dessa sociedade como produtora de mercadorias, a lei da mais-valia, forma capitalista da lei do valor, é a lei que governa a reprodução em escala ampliada das relações capitalistas e determina as suas possibilidades e limitações.

18 Ver Marx (1975, p. 73-88); Ver também Oliveira (1977) e Tavares (1978, p. 44).

19 Ver observações de (MARX, 1975, p. 78-79 e 89-92) e Napoleoni (1981, cap. 6 e 7).

20 Produtividade do Trabalho, portanto, significa o máximo de produção de mercadorias socialmente necessárias com um mínimo de força de trabalho - o que implica em barateamento geral das mercadorias oriundas da indústria e da agricultura. Ver Marx (op. cit. cap. XV, p. 604-607).

21 Não se pretende aqui revisar a discussão, levada a cabo por vários autores, do significado da elevação da composição orgânica do capital, como reflexo da relação entre desenvolvimento das forças produtivas sociais e a reprodução ampliada das relações de produção, suficientemente esclarecido por Belluzzo (op. cit. p. 92-96).

22 Ver Marx (1980, l 1, v. 1,seção IV, cap. X a XIII).

23 Uma ampla análise sobre as crises do capitalismo pode ser vista em Colletti (1985) e Mazzucchelli (1985).

24 A formulação de leis de movimento do capital, a partir da lei de apropriação e valorização, coloca duas ordens de problemas - o problema da transformação de valores a preços de produção e o da vinculação entre as leis de movimento e a lei de autovalorização do capital- abordados por Possas (1989, p. 18-21).

25 Isso se apresenta, de um lado, como uma lei na medida em que o capitalista que produz em pequena escala estaria incorporando no produto uma quantidade maior do que o socialmente necessário; mas aparece, do outro lado, como um impulso do capitalista individual que, para violar a lei do valor em sua forma capitalista, procura rebaixar o valor individual da sua mercadoria abaixo do valor socialmente determinado pelo mercado. Ver Marx (1975, op. cit., p. 92).

26 Ver Marx (1975, L. 1, v. 2, p. 726).

27 Ver comentários sobre concorrência e ambiente seletivo em Silvia (1999, cap. 4).

28 A expressão crédito deve ser entendida como sistema de crédito, pois inclui não só os bancos comerciais, mas os bancos de investimento, o mercado de capitais e o mercado financeiro. Ver Marx (1975, 1.1, v. 2, p. 727-730).

29 Ver Hilferding (1985, cap. VII-VIII); Sweezy, Paul M. (1976, p. 287-300).

30 Ver Possas (1987, p. 71-73).

31 Ver Possas (1987, p. 16).

32 Ver Possas (1987, p. 76-77).

33 Ver Possas (1987, p. 61-65).

34 Ver Possas (1987, p. 15-16).

Teoria e Evidência Econômica - Ano 20, n. 42, p. 157-194, jan./jun. 2014 
6 Ver comentários de Possas (1987, p. 23-33).

7 Admitindo por razões metodológicas a existência de dois níveis de relação para se abordar a dimensão histórica e econômica, numa perspectiva teórica, uma teoria sobre o funcionamento de uma economia real deve supor, pelo menos, uma relação de compatibilidade com as determinações econômicas gerais do movimento do capitalismo. Isto significa que é análise teórica da dimensão econômica ao nível da concorrência capitalista - onde ocorrem, em diferentes graus, as mudanças das forças produtivas e das relações econômicas - deve preservar a mesma dimensão histórica com as características básicas e gerais do modo de produção capitalista. Ver Possas (1987, p. 31-32).

38 Uma discussão atualizada do "problema da transformação de valores em preços" pode ser vista em Possas (1985, cap. 3); Ver também Morishima e Catephores (1980, cap. 7).

39 Uma discussão epistemológica pode ser vista em Cutler et alli (1980, v. 1, cap. 4, p. 101-125). Possas (1989, p. 25-53), apresenta uma interessante discussão sobre o significado de tendência em Marx e seus interpretes. Quanto à lei de tendência da queda da taxa de lucro, enquanto lei - síntese de manifestação da tendência do declínio da taxa de lucro geral, utilizada por alguns marxistas dogmáticos para demonstrar o colapso do capitalismo, penso que esta tem mais um significado lógico do que histórico. De fato, tal como no conceito matemático de limite, embora o limite do polígono seja o círculo, por mais que se divida os lados do polígono nunca se terá um circulo.

40 A concorrência em Marx é vista como o espaço da representação e da percepção ilusória dos atores econômicos - e não só os capitalistas - a respeito de suas atividades (onde a mais - valia é obscurecida pelo valor adicionado na forma de salário, lucro, juro e renda da terra) e das leis gerais de movimento (tornadas ininteligíveis na esfera anárquica da circulação) que a reagem. Daí a virtual identificação entre o âmbito da concorrência e a órbita da circulação das mercadorias e do capital, ocultando - se, assim, as relações sociais de produção original da valorização do capital. Ver a esse respeito os comentários de Possas (1987, p. 55-59) e de Semmler (1979, p. 5).

41 Ver Marx (1980a, v. II, p. 621-641). Ver ainda interessantes observações de Coutinho (1997, p. 146-148).

42 As condições de concorrência consistem na mobilidade do capital e o grau com que a "livre mobilidade" se verifica um indicador da intensidade da concorrência ao nível dos capitais plurais.

43 Ver Grundrisse (1987, v. II, p. 175); Grundrisses (1987, v. I, p. 268). Marx (1980a, v. I, p. 13).

44 Essa crítica Marx (1980a, v. II, p. 620-621) já tinha feito a Ricardo. Ver Mazzucchelli (1985, p. 52).

\section{Referências}

BALIBAR, Étienne (1980). Sobre os Conceitos Fundamentais do Materialismo Histórico. In: Althusser, Louis, Balibar, Étienne \& Establet, Roger. Ler o Capital. Rio de Janeiro: Zahar.

BAUMOL, W. The Transformation of Values: What Marx "Realy" Meant (An interpretation). Journal of Economic Literature, 12, march. 1974.

BELLUZZO, Luiz Gonzaga de Mello. Valor e capitalismo: um ensaio sobre a economia política. São Paulo: Brasiliense. 1980.

CLIFTON, J. Competition and Evolution of the Capitalist Mode of Production. In: Cambridge Journal of Economics, v. 1, n. 1. 1977.

COUTINHO, Maurício Chalfin. Marx: notas sobre a teoria do capital. São Paulo: Hucitec, 1997. COLLETTI, Lúcio. El Marxismo y el "Derrube" del Capitalismo. Madrid: Siglo Veintiuno, 1985.

CULTLER, Antonio et al. O Capital de Marx e o Capitalismo de hoje, v. 1. Rio de Janeiro: Zahar. 1980 .

ENGELS, Friedrich. O Capital de Marx. In: MARX, Karl; FRIEDRICH, Engels. 1980. Obras escolhidas: São Paulo: Alfa - Omega. 1868. 
GIANNOTTI, José Arthur. Trabalho e reflexão: ensaios para uma dialética da sociabilidade. São Paulo: Brasiliense, 1984.

HILFERDING, Rudolf. El Capital Financiero. Madrid: Tecnos, 1985.

OLIVEIRA, Carlos Alonso Barbosa. Considerações sobre a formação do capitalismo. Campinas: IE/Unicamp, 1977. (Mimeo.).

MAZZUCCHELLI, Frederico. A contradição em processo: o capitalismo e suas crises. São Paulo: Brasiliense, 1985.

MARX, Karl. Carta de Marx a Engels em 31/05/1858. In: BARCELONA, Laia. Cartas sobre O Capital. Barcelona: Laia, 1974. corpião, 1975.

Capítulo inédito d'O Capital: resultados do processo de produção imediato. Porto: Es. Introdução à crítica da economia política. In: Contribuição à crítica da economia política. São Paulo: Martins Fontes, 1977.

. O Capital (Crítica da Economia Política). Rio de Janeiro: Civilização Brasileira. Livros. I, II e III. 1980.

Teorias da Mais-valia: história crítica do pensamento econômico. Rio de Janeiro: Civilização Brasileira. v. I e II. 1980a.

Elementos fundamentales para la crítica de la economia política (Grundrisse) 1857-1858. México: Siglo XXI, v. 1 e 2, 1987.

MELLO, João Manuel Cardoso de. O capitalismo tardio: contribuição à revisão crítica da formação e do desenvolvimento da economia brasileira. São Paulo: Brasiliense, 1982.

MORISHIMA, M.; CATEPHORES, G. Valor, exploração e crescimento. Rio de Janeiro: Zahar. 1980.

NAPOLEONI, Claudio Lições sobre o capítulo sexto (inédito) de Marx. São Paulo: Ciências Humanas, 1981.

POSSAS, Mario Luiz. Dinâmica da economia capitalista: uma abordagem teórica. São Paulo: Brasiliense, 1987.

POSSAS, Mario Luiz. Dinâmica e concorrência capitalista: uma interpretação a partir de Marx. São Paulo: Hucitec/Unicamp, 1981.

POSSAS, Silvia. Concorrência e competitividade: notas sobre estratégia e dinâmica deletiva na economia capitalista. São Paulo: Hucitec, 1999.

ROSDOSLKY, Roman. Génesis y estructura de el capital de Marx (estudios sobre los Grundrisse). México: Siglo XXI. 1985.

SEMMLER. Competition and monopoly power: theories and emprical evidence. Washington, D. C.: American University. (Mimeo.) 1979.

SWEEZY, Paul M. Teoria do desenvolvimento econômico capitalista. Rio de Janeiro: Sahar, 1976.

TAVARES, Maria da Conceição. Ciclo e crise: o movimento recente da industrialização brasileira. Rio de Janeiro: UFRJ, 1978. (Mimeo.). 